\title{
電界中における多孔質円筒バーナー拡散火炎の挙動*1 Diffusion Flame Behavior by a Burner of Porous Cylinder in Electrical Fields
}

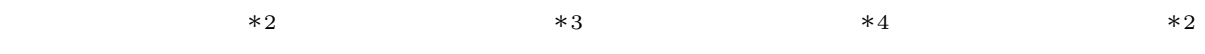 \\ Kiyotaka Yamashita, Lin Xie, Osamu Imamura, Jun Osaka, \\ 津 江 光 洋 ${ }^{* 2} \cdot$ 河 野 通 方*4 \\ Mitsuhiro Tsue and Michikata Kono
}

Key Words : Ionic Wind, Counter-Flow Flame, Electrical Field

\begin{abstract}
The acetylene/air counter flow flame formed by a porous cylinder in electrical fields was studied experimentally and numerically. The temperature and $\mathrm{OH}$ radical distributions in the flame were measured in experiments. The numerical simulation with a detailed reaction model was conducted to explore the effect of ionic wind on the flame behavior. The experimental results show that the temperature and $\mathrm{OH}$ radical distribution shifts to the negative electrode side in electrical fields, which is good agreement with the prediction. It is indicated that the shift of flame zone in electrical fields may be due to the change in the bulk flow velocity induced by the ionic wind.
\end{abstract}

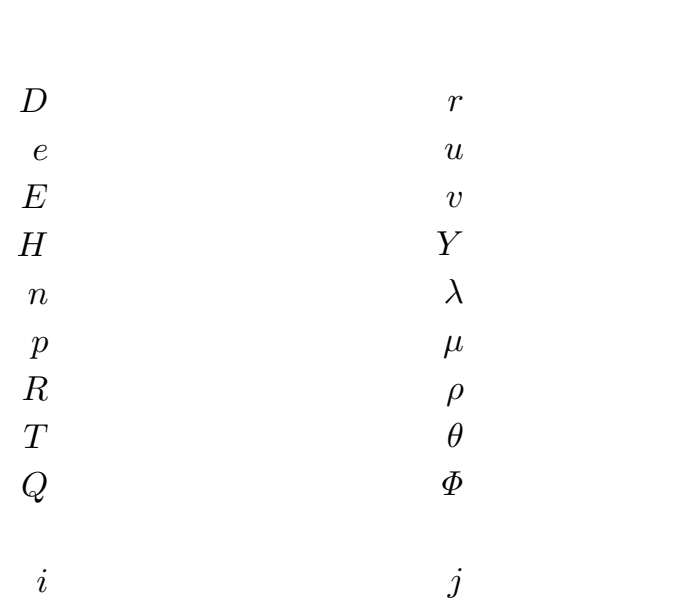

1. 緒 論

電界中における火炎の挙動については, 過去多くの研究 がなされてきた，弚れらは, 火炎の形状, 発光, 安定性, す すの生成メカニズムなどと多岐にわたる．火炎の変化は電 荷を帯びたイオン粒子が中性ガスを介して流体に運動量を 与えて生じる流れ (イオン風) に起因すると考えられてい るが, 火炎中における荷電粒子発生に起因するローレンツ 力および電場の変化, 電荷を持ったすす粒子の影響など複 数の要素が密接に関連すると言われる. また，燃焼速度に 関して電界の影響はあるとする意見 ${ }^{1,2)}$, 無いとする意見 ${ }^{3)}$

\footnotetext{
*1 (C) 2006 日本航空宇宙学会

平成 18 年 3 月 16 日原稿受理

$* 2$ 東京大学工学系研究科航空宇宙工学専攻

*3 (株) ノーリツ・基礎研究所

$* 4$ 東京大学新領域創成科学研究科
}

もあるなど現象解明はまだ不十分な点が多い.一方, 火炎 に対して電界を印加すると挙動が変化するという性質を利 用することで能動的な火炎の制御への適用が考えられる. また燃焼器の燃焼効率の改善や，すすの生成の抑制にもつ ながる．これより，環境負荷を低減させることができる．

従来より燃焼挙動に及ぼす電界の影響に関する実験的な 研究は数多く行われてきたのに対して, 数値計算による解 析はほとんど行われていない．解析されたモデルも数十式 程度の反応式による一次元対向噴流火炎 ${ }^{4)}$ や二次元平行噴 流火炎 ${ }^{5)}$ が見られる程度である . 燃焼に関する問題は他に も多くの実用機器に則したモデルが考えられるが電界下で の挙動に関する解析についてはほとんど報告されていない . 弚こで, 本研究では電界中での燃焼について複数ある因 子の中でも最も影響が大きいとされるイオン風の影響のみ を考慮した解析を行う. 扱うモデルは, 比較的流れが安定 でかつ解析が容易という特徽を持つ多孔質円筒バーナー火 炎である．アセチレンを燃料として火炎を形成させ , ここ に電界を印加し, 弚の挙動の変化を観測する. 同時に電界 の影響と考えられるイオン風を加味した方程式を離散化し たモデルで数值計算を行い, 詳細な各輸送変数の分布の推 移より, 実験との比較を合わせて電界下でのイオン風の火 炎への影響について考察する。

多孔質円筒バーナーは, 辻らのものを元に作成された ${ }^{6)}$.

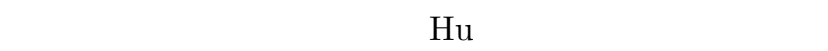
フト速度, 運動量保存式の体積力項を加味する手法5)を採 用した。

$$
\text { 2. 実験 }
$$

2.1 実験装置と方法 過去に著者らの一部が製作した 
装置》を用いて実験を行う．第 1 図に実験装置の概要を示 す．一樣流条件を得るために風洞に連結された測定部に多 孔質円筒バーナーを設置した .この装置の特徵としては淀 み点近傍の流れか極めて安定しており，火炎の形状が二次 元的であるため，測定結果の解析が比較的容易であること が挙げられる.

バーナーは, 外径 $60 \mathrm{~mm}$ 奥行き $44 \mathrm{~mm}$ 全長 $50 \mathrm{~mm}$ と なっており，表面から燃料と不活性ガスか噴出する .円筒の 両端に軟鋼製の蓋が取り付けられており，兴の一端はバー ナー支持棒を兼ねた燃料供給用のパイプが取り付けられた 一体構造となっている.バーナーは石綿パッキンを介して 2 枚の蓋にはさまれた状態で , バーナー支持棒に固定され ている . 不活性ガスは火炎がバーナー表面に付着するのを 防ぐために使われた .

一樣流はコンプレッサーから出た圧縮空気をサージタン クで一度溜めて精密減圧弁, 面積流量計を通過して風洞内 に送り込まれる。

風洞は入り口部, 拡大管, 整流部, 縮流管で構成されてお りバーナーか設置されている測定部につながっている．入

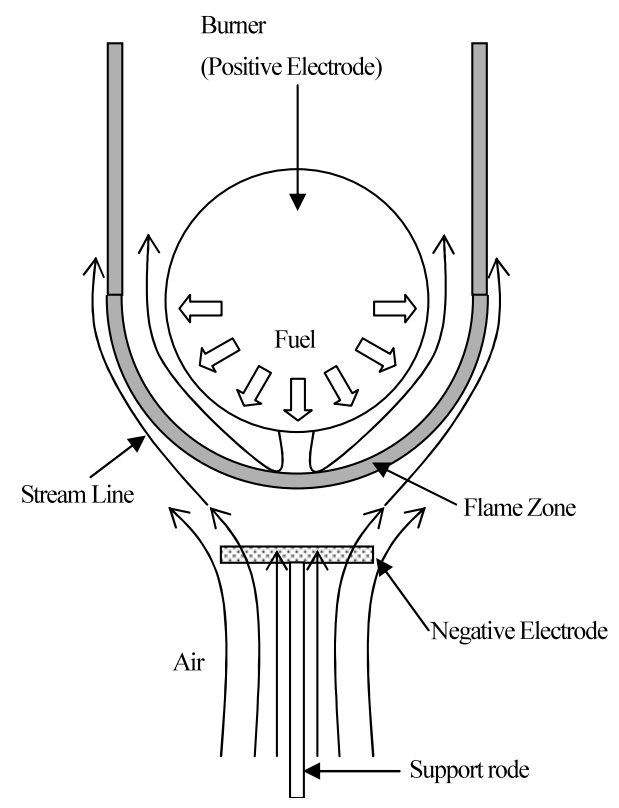

第 1 図 バーナー (陽極) と金網電極 (陰極)
り口部は内径 $70 \mathrm{~mm}$ ，拡大管は広がり角が 90 度で断面形 状は正方形である.整流部は内側寸法 $440 \mathrm{~mm} \times 440 \mathrm{~mm}$ で高さが $450 \mathrm{~mm}$ あり，10段分割され，中には八ニカム層・ アルミニウム多孔板が設置されている．縮流管は測定部ま で円弧状に接続されている。

また燃料はアセチレンガス, 不活性ガスは窒素を用いて同 樣に流量計をはさんでバーナーに送り込まれた .アセチレン は浮遊式流量計, 室素は差圧式流量計である.いずれも独立 のニードルバルブて調節された . 流量は空気が $225 \mathrm{l} / \mathrm{min}$, アセチレンが $0.73 \mathrm{l} / \mathrm{min}$, 室素が $8.9 \mathrm{l} / \mathrm{min}$ で行った .

電界を印加するための電極には金網電極を用い, バー ナー表面から $10 \mathrm{~mm}$ の位置に設置された . 金網は外径 $0.3 \mathrm{~mm}$ の管で作られた格子 (ピッチ $2 \times 4 \mathrm{~mm}$, 外寸 $27 \mathrm{~mm}$, $5 \times 50 \mathrm{~mm})$ でできており，格子状電極か持つ静電容量をお さえるためにステンレスパイプ (外径 $0.3 \mathrm{~mm}$ ) を使った . 電界はバーナーを陽極，金網電極を陰極となるように電圧 を与えることで印加された．実験方法を示す．一樣流（空 気）を流した状態でバーナー表面より燃料と不活性ガスを 噴出させることにより，バーナー表面近傍に不輝炎の火炎 を形成させた .

実験条件は, 酸化斉流量 $235 \mathrm{l} / \mathrm{min}$ ・燃料 (アセチレン) 流量 $0.73 \mathrm{l} / \mathrm{min}$ ・不活性ガス (窒素) $8.9 \mathrm{l} / \mathrm{min}$ で, 印加電 圧は DC $200 \mathrm{~V}$ とした。

計測装置の概要を第 2 図に示す . 温度分布は LIFS ${ }^{8)}$ 用いて測定された．装置は主として 3 つの部分より構成さ れている. 波長可変レーザ光発生装置, 蛍光受光装置, 遅 延パルス発生器である。

波長可変レーザ光発生装置は, $10 \mathrm{~Hz}$ のパルス $\mathrm{Nd}$ : YAG

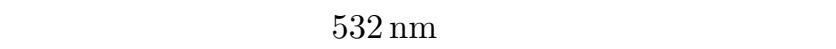
ンピングした . 出力波長を $618 \mathrm{~nm}$ とするため，色素はサ ルフォーダミン 640 を用いた . 色素レーザから出力された レーザ光を波長倍波装置に入射し，装置中の結晶でレーザ 光には入射光の $618 \mathrm{~nm}$ も含まれているため, UV 透過フィ ルタにより $618 \mathrm{~nm}$ のレーザ光もカットした .レーザ光は焦 点距離 $500 \mathrm{~mm}$ の石英レンズで火炎中の測定点に入射され た．蛍光はレーザ光と直角方向において焦点距離 $120 \mathrm{~mm}$ の石英レンズを用いて集光された . 光の後, UV 透過レンズ で可視光をカットし, オプティカルファイバを介して分光器

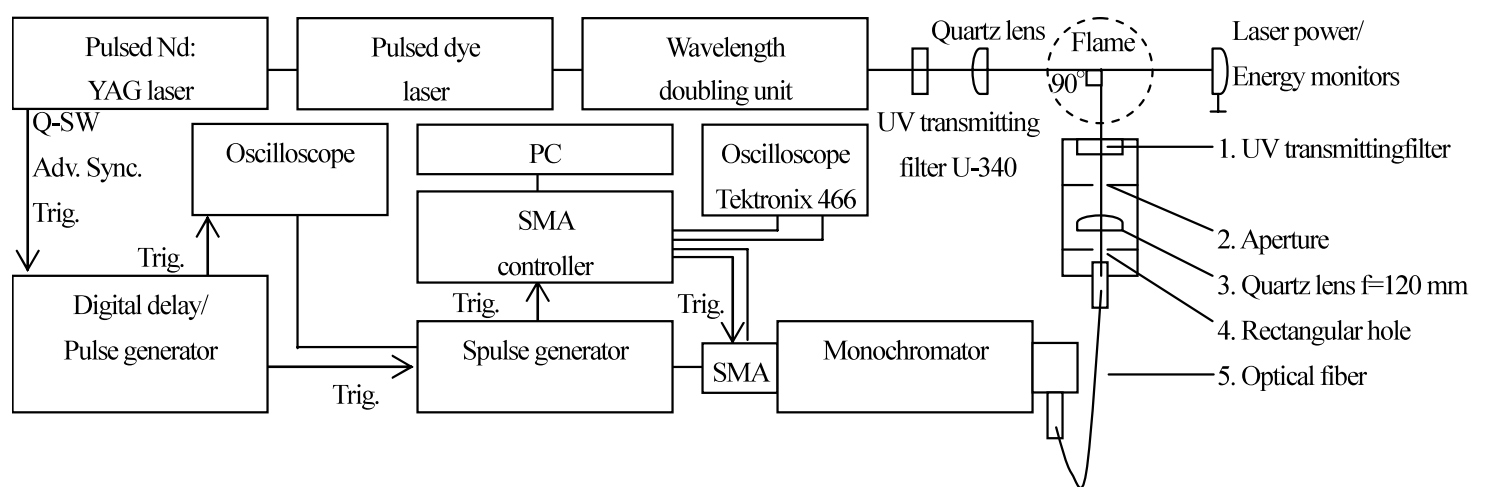

第 2 図 光学系測定装置の概略 


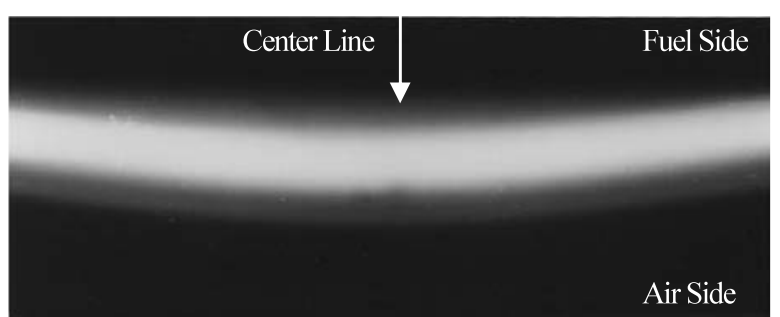

(a) Without electrical field

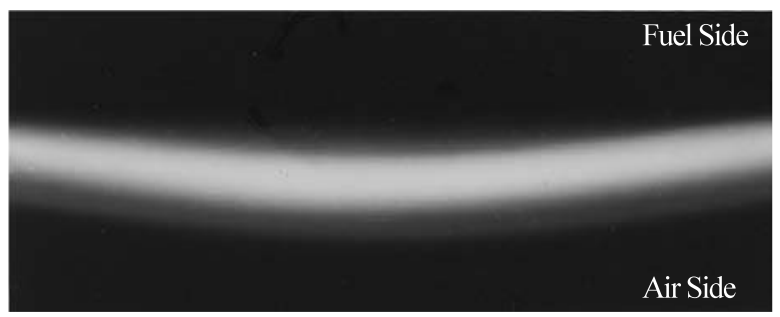

(b) With electrical field

第 3 図 拡散火炎の直接写真

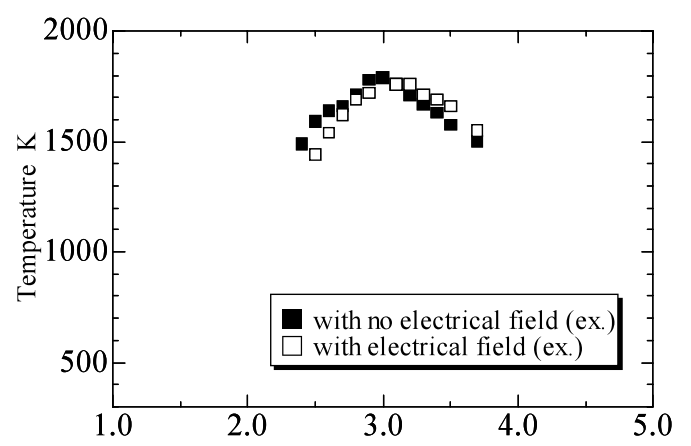

- Fuel side -

- Air side -

Distance from the burner surface $\mathrm{mm}$

第 4 図 実験結果 (温度分布)

に通され SMA (Spectrometric Multichannel Analyzer) で則定した。

これらの装置を用いて得られた蛍光強度より, 温度分布 を測定した。なお，電圧を印加していない場合において熱 電対により温度分布を測定した結果は本手法の測定値とよ く一致していることを確認した . また $\mathrm{OH}$ 濃度分布はレー ザ飽和蛍光法を用いて測定された．なお，本研究では $\mathrm{OH}$ ラジカルの分布形状を見るために，電界を印加しない場合 の拡散火炎におけるバーナー表面より $2.5 \mathrm{~mm}$ の位置での 濃度を 1 とした時の相対値で $\mathrm{OH}$ 濃度分布を求めた。

2.2 実験結果と考察 電界を印加した場合と印加しない 場合のバーナー近傍の火炎の直接写真を第 3 図に示す . ま た第 4 図には半径方向に対する温度分布, 第 5 図には $\mathrm{OH}$ 分布を示す. 横軸はバーナー表面からの距離を表す. 第 4 图から火炎帯がバーナー表面から $3.0 \mathrm{~mm}$ 程度の位置に形 成されていることがわかる．電圧を印加した場合，印加し ていない場合よりも空気側に移動している。

これについて以下に考察を与える．すなわち電圧が印加 され一樣電界が形成されたことにより火炎面の陽イオンは

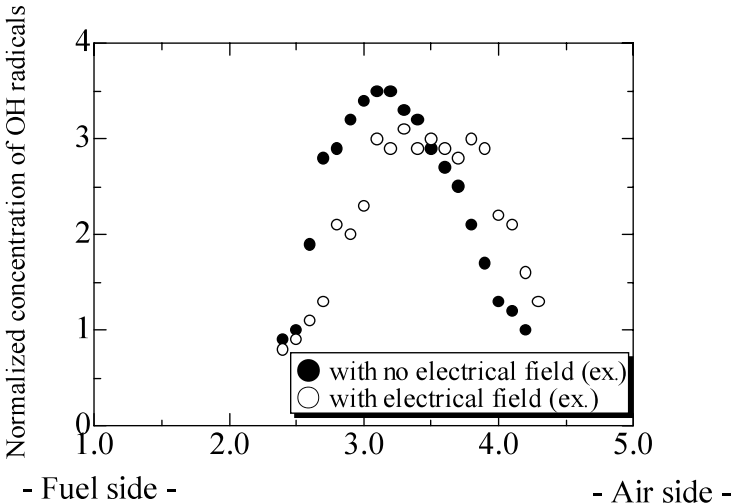

Distance from the burner surface $\mathrm{mm}$

第 5 図実験結果 $(\mathrm{OH}$ 分布)

クーロンカを受け加速される . 同樣に陰イオンや電子も力 を受け陽イオンとは逆方向に加速されるが，火炎中では陽 イオンに比べてはるかに衝突頻度が低いことが知られてお り ${ }^{9)}$ 体積力としては無視される．陽イオンが中性ガス粒子 と衝突した結果，流体に対して運動量が与えられ，全体が 陽極から陰極の方向へと移動したと考えられる．なお，第 3 図から電界中では火炎発光帯幅が若干狭くなっており，ま た第 4 図から火炎の最高温度は約 $10 \mathrm{~K}$ 低くなっていること がわかる.この火炎温度低下は Heinsohn ら ${ }^{10)}$ も報告して いるように電界による火炎発光帯幅が狭くなった結果，体 積あたりの発熱量が減少したためであると考えられる．し かしながら，光の詳細なメカニズムは未だ不明である．第 5 図より温度分布同樣に電界印加により $\mathrm{OH}$ 濃度分布が空 気側に移動していること，濃度のピーク值が電界印加によ り小さくなっていることがわかる .

$\mathrm{OH}$ 濃度の減少については火炎温度の低下が光の要因の一

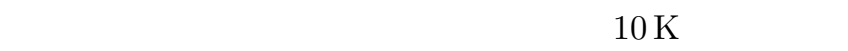
炎温度低下のみで説明することはできないように思われる．

\section{3. 計算}

3.1 計算方法と条件 実験を模擬した数值計算を行っ た.基礎方程式を以下に示す。

·質量保存式

$$
\frac{\partial \rho}{\partial t}+\frac{\partial(\rho u)}{\partial r}+\frac{1}{r} \frac{\partial(\rho v)}{\partial \theta}=0
$$

·運動量保存式

$$
\begin{aligned}
& \frac{\partial(\rho u)}{\partial t}+\operatorname{div}(\rho \boldsymbol{u u}) \\
& \quad=\operatorname{div}(\rho \nu \operatorname{grad} u)-\operatorname{grad} p+B_{r} \\
& \frac{\partial(\rho v)}{\partial t}+\operatorname{div}(\rho \boldsymbol{u} v) \\
& \quad=\operatorname{div}(\rho \nu \operatorname{grad} v)-\operatorname{grad} p+B_{\theta}
\end{aligned}
$$

・エネルギー保存式

$$
\frac{\partial(\rho H)}{\partial t}+\operatorname{div}(\rho \boldsymbol{u} H)
$$




$$
=\operatorname{div}(\lambda \operatorname{grad} T)+\frac{\partial p}{\partial t}+\boldsymbol{u} \cdot \operatorname{grad} p+\Phi+Q
$$

- 化学種保存式

$$
\frac{\partial\left(\rho Y_{i}\right)}{\partial t}+\operatorname{div}\left(\rho \boldsymbol{u} Y_{i}-\rho D_{i} \operatorname{grad} Y_{i}\right)=R_{i}
$$

また，第 6 図に計算領域を示し，第 1 表に計算概要を示す。 基礎方程式を有限体積法により計算した . 対象とする流れ 場および座標系は，二次元円筒座標系で領域下部から一樣 空気流が流入しているものとする．特に実験との比較をす るべきバーナー表面近傍の流れ場のみに注目するため，円 筒座標のうち右下 $1 / 4$ のみの計算領域としている . 格子に ついては火炎帯付近が高解像度になるよう不等間隔で配置 し，また紙面垂直方向は周期境界条件として扱っている.よ どみ点位置は点線で囲ったあたりになる．電極の配置につ いては , 格子の性質上円周に沿った配置にせざるをえない ため, 図に示すように実問題とほぼ同じ位置でかつ曲率が 小さくなるように配置してある . しかし注目すべき部分は よどみ点を通る流線であることから，全体の流れ場が実験 同樣に形成されていれば特に問題が無いものと判断した .

化学反応機構は GRI-MECH3.0 ${ }^{11)}$ の素反応式 325 式お よび第 2 表に示す 13 イオン反応式を用いた .この反応式 はPedersen ら ${ }^{12)}$ の手法を参照した .

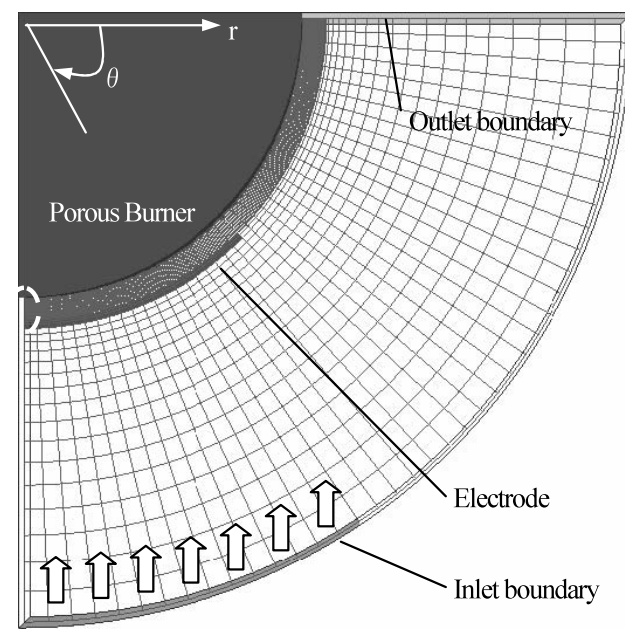

第 6 図 計算領域
また , 電界の影響を加味した体積力項は次式の通りである .

$$
B_{r}=E e n_{+}=E e A_{0} \rho\left(\sum_{j} \frac{\rho_{j}}{W_{j}}\right)
$$

ここで $n_{+}$は陽イオンの粒子数， $A_{0}$ はアボガドロ数であ り, $n_{+}$はセルあたりの質量分率と数密度から求めている. 体積力項は (2) 式に付加される .

またイオン化学種のドリフト速度は次式の通りである .

$$
v_{i}=\mu E
$$

ドリフト速度項は (5) 式の速度項に付加される .これらの

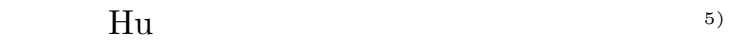

また，本計算では以下の仮定をした．

(1) イオン分布による電界の変化は考慮していない.

(2) 陽イオンの体積力は $r$ 方向のみを考える .

(3) 電子や陰イオンの体積力は無視する .

(4) 磁界による流体への体積力は考えない .

(5)すすの生成・流れ場への影響も考慮していない . なお本研究での実験は一般的にすすの生成を伴うアセチレ ンを燃料としているが, 不活性ガスを大量に混合させ充分

\begin{tabular}{lc}
\multicolumn{1}{c}{ 第 1 表 } & 計算概要 \\
\hline 計算方法 & 有限体積法 \\
空間離散化 & 完全陰解法 \\
時間離散化 & Simplest 法 \\
圧力速度 & $\theta: 40, r: 40$ \\
格子数 & $\theta: \pi / 80 \mathrm{rad}, r:$ 不等間隔 \\
格子間隔 & $\Delta t=0.01 \mathrm{~s}$ \\
時間間隔 & $1000 \mathrm{step}$ \\
計算ステップ & \\
境界条件 & $298 \mathrm{~K}$ \\
燃料温度 & $0.73 l / \mathrm{min}$ \\
燃料流量 & $298 \mathrm{~K}$ \\
不活性ガス温度 & $8.9 l / \mathrm{min}$ \\
不活性ガス流量 & $298 \mathrm{~K}$ \\
酸化剂温度 & $235 l / \mathrm{min}$ \\
酸化剂流量 & 338 \\
化学反応式 & 60 \\
化学種 & $200 \mathrm{~V}$ \\
印加電圧 & - 樣電界 \\
印加方法 & \\
\hline &
\end{tabular}

第 2 表 イオン化学種反応式とアレニウス係数 $\left(k=A T^{b} \exp \left(-E_{\mathrm{a}} / R T\right)\right)$

\begin{tabular}{clccc}
\hline & \multicolumn{1}{c}{ Reaction } & $A$ & $n$ & $E_{\mathrm{a}}[\mathrm{cal} / \mathrm{mol}]$ \\
\hline$(1)$ & $\mathrm{CH}+\mathrm{O}=\mathrm{CHO}^{+}+\mathrm{e}^{-}$ & $2.51 \mathrm{E} 11$ & 0.0 & 7110 \\
$(2)$ & $\mathrm{CH}^{*}+\mathrm{O}=\mathrm{CHO}^{+}+\mathrm{e}^{-}$ & $5.01 \mathrm{E} 14$ & 0.0 & 7110 \\
$(3)$ & $\mathrm{CHO}^{+}+\mathrm{H}_{2} \mathrm{O}=\mathrm{H}_{3} \mathrm{O}^{+}+\mathrm{CO}$ & $1.00 \mathrm{E} 16$ & -0.0897 & 0 \\
$(4)$ & $\mathrm{H}_{3} \mathrm{O}^{+}+\mathrm{C}_{2} \mathrm{H}_{2}=\mathrm{C}_{2} \mathrm{H}_{3} \mathrm{O}^{+}+\mathrm{H}_{2}$ & $8.39 \mathrm{E} 15$ & 0.0 & 0 \\
$(5)$ & $\mathrm{CHO}^{+}+\mathrm{CH}_{2}=\mathrm{CH}_{3}^{+}+\mathrm{CO}$ & $5.62 \mathrm{E} 14$ & -0.060 & 0 \\
$(6)$ & $\mathrm{H}_{3} \mathrm{O}^{+}+\mathrm{CH}_{2}=\mathrm{CH}_{3}^{+}+\mathrm{H}_{2} \mathrm{O}$ & $6.17 \mathrm{E} 14$ & -0.060 & 0 \\
$(7)$ & $\mathrm{CH}_{3}^{+}+\mathrm{C}_{2} \mathrm{H}_{2}=\mathrm{C}_{3} \mathrm{H}_{3}^{+}+\mathrm{H}_{2}$ & $7.24 \mathrm{E} 14$ & 0.0 & 0 \\
$(8)$ & $\mathrm{C}_{3} \mathrm{H}_{3}^{+}+\mathrm{H}_{2} \mathrm{O}=\mathrm{C}_{2} \mathrm{H}_{3} \mathrm{O}^{+}+\mathrm{CH}_{2}$ & $7.24 \mathrm{E} 14$ & 0.0 & 0 \\
$(9)$ & $\mathrm{CH}_{3}^{+}+\mathrm{CO}_{2}=\mathrm{C}_{2} \mathrm{H}_{3} \mathrm{O}^{+}+\mathrm{O}$ & $7.24 \mathrm{E} 14$ & 0.0 & 0 \\
$(10)$ & $\mathrm{H}_{3} \mathrm{O}^{+}+\mathrm{e}^{-}=\mathrm{H}_{2} \mathrm{O}+\mathrm{H}$ & $2.29 \mathrm{E} 18$ & -0.5 & 0 \\
$(11)$ & $\mathrm{C}_{3} \mathrm{H}+\mathrm{O}_{2}=\mathrm{CH}^{*}+\mathrm{CO}_{2}$ & $4.50 \mathrm{E} 15$ & 0.0 & 25000 \\
$(12)$ & $\mathrm{CH}_{3}^{+}+\mathrm{e}^{-}=\mathrm{CH}_{2}+\mathrm{H}$ & $2.29 \mathrm{E} 18$ & -0.5 & 0 \\
$(13)$ & $\mathrm{C}_{2} \mathrm{H}+\mathrm{O}=\mathrm{CH}^{*}+\mathrm{CO}$ & $7.10 \mathrm{E} 11$ & 0.0 & 0 \\
\hline
\end{tabular}


希釈しており，すすの影響を考慮しない計算で模擬しうる と考える .

3.2 計算結果と考察 これ以降の諸量の分布は特に断 らない限り，第 5 図の $\theta=90^{\circ}$ の軸上の分布を表す. ま ず，第 7 図 (a)，(b) に定常状態に至った時の流れ場の温度 等高線分布および速度べクトル分布を示す . 温度場は 300 , $500,1000,1500,1800 \mathrm{~K}$ で等高線を引いている.これよ り高温部，すなわち火炎帯がバーナー近傍に形成されてい ることがわかる．また速度べクトル分布の結果より，円筒 バーナー表面に沿った流れ場が形成されていることがわか る.次に第 8 図に, 電界を印加した場合 $(V=200 \mathrm{~V})$ と 印加しなかった場合 $(V=0 \mathrm{~V})$ の温度分布を示す.まず， $0 \mathrm{~V}$ につい $r=2.70[\mathrm{~mm}]$ 付近に最高温度の分布が見ら れる.これに対して $V=200 \mathrm{~V}$ の場合 $r=2.72[\mathrm{~mm}]$ の位 置に分布形状を保ったまま移動している，すなわち，電界 の印加により火炎位置が移動していることがわかる.なお 最高温度については実験結果と異なり，電界を印加された 場合もほとんど変化が見られない．また火炎帯位置も実験 值に比へててやや燃料側に寄っている．この原因としては本 計算においては，電界による火炎への影響はイオン風のみ しか考慮しておらず, 火炎が存在することによる電場の変 化などの他の因子が影響を及ぼしていることが考えられる．

第 9 図に, $\mathrm{OH}$ ラジカルの濃度分布を示す.上述の通り 最高温度の減少はほとんど見られなかったが, 電界印加時 の $\mathrm{OH}$ 濃度は低下している．したがって，本計算結果から， 火炎温度の低下が $\mathrm{OH}$ 濃度減少の主たる要因であるとは言 えないものと思われる. 他の要因としては, 電界印加によ

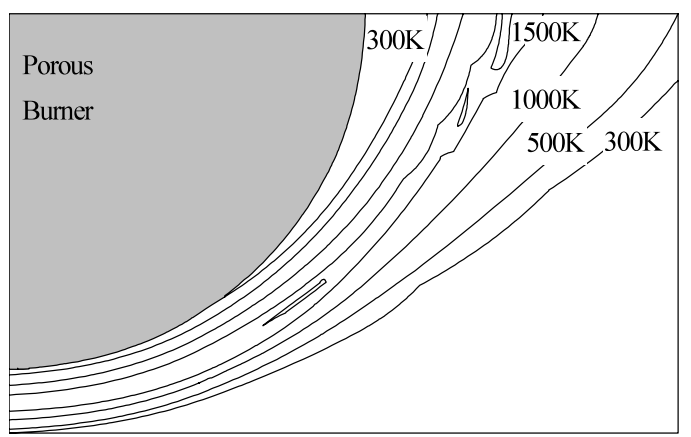

(a) バーナー近傍の温度場

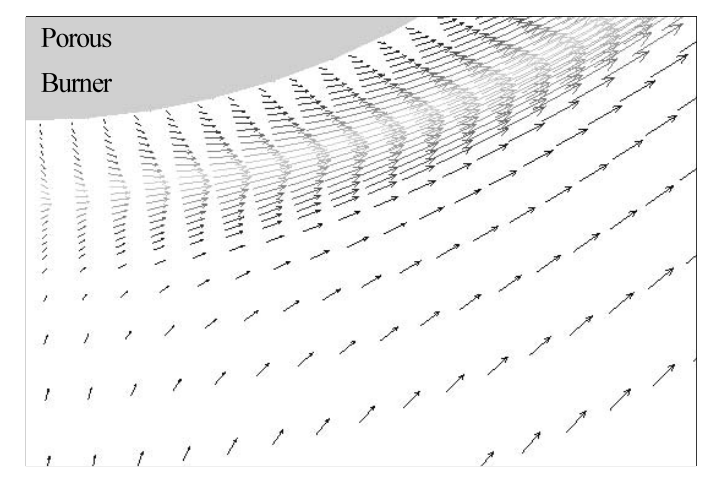

(b) バーナー近傍の速度場

第 7 図 定常状態の流れ場の形成
るイオン粒子の挙動の変化および光れに伴うイオン反応以 外の化学反応挙動の変化等が考えられる.また上述のよう に, 火炎の存在による電場の変化が何らかの影響を及ぼし ていることも推察されるが，いずれにしても本計算におい ては明確な根拠は見出せなかった . また印加による分布位 置の空気側への移動が見られたが，ピークよりも空気側で は印加前よりも燃料側に移動していた．しかし，実験值に 見られるような第二ピーク $(r=3.8 \mathrm{~mm}$ 付近) のような分 布は見られなかった .これについても，上述のようなイオ ン風以外の要因か関係しているものと思われる . また , 計 算に用いられた素反応式についても解析モデルによって最 適条件が変わりうるため, 本計算の反応モデルとして最適 なものとは言えないことも考えられる.特に，イオン反応 式については，不明な点が多く残されている．

しかし，本計算の主旨であるイオン風の影響は温度場な らびに $\mathrm{OH}$ ラジカルの分布の空気側への移動から定性的に は，ほぼ正しく模擬されていたと言える．

さらに，現象を詳細に見るため，電界の影響を担ったイ オンの分布と半径方向の速度分布を第 10 图および第 11 図 に示し，これについて考える。

第 10 図にイオン化学種の中で最も質量分率の大きかった $\mathrm{C}_{2} \mathrm{H}_{3} \mathrm{O}^{+}$イオンの濃度分布を示す . 電界印加後では , 印加 前よりもイオン総量か増えている.これは, $\mathrm{C}_{2} \mathrm{H}_{3} \mathrm{O}^{+}$イオ

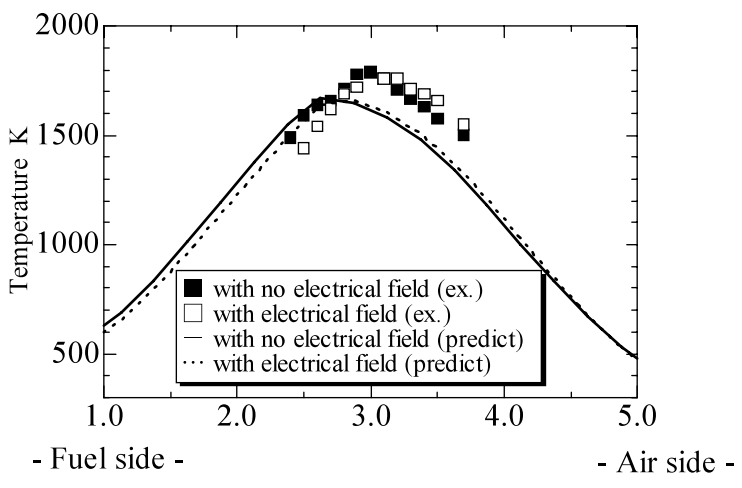

Distance from the burner surface $\mathrm{mm}$ 第 8 図 計算結果 (温度分布)

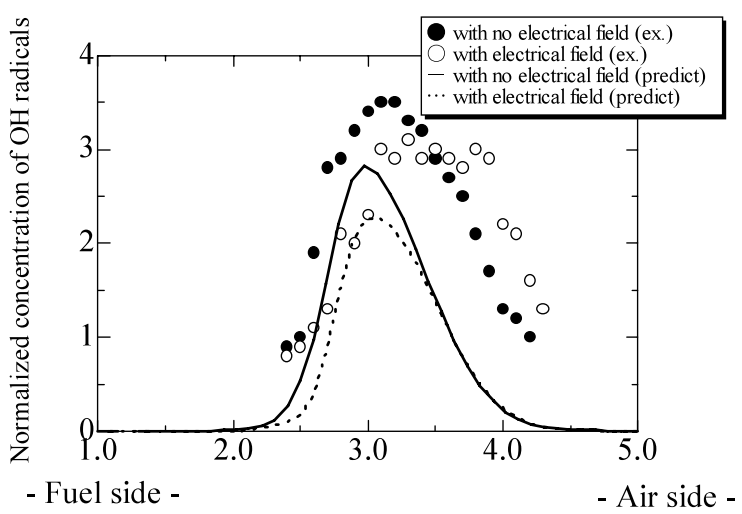

Distance from the burner surface $\mathrm{mm}$ 第 9 図計算結果 $(\mathrm{OH}$ 分布) 


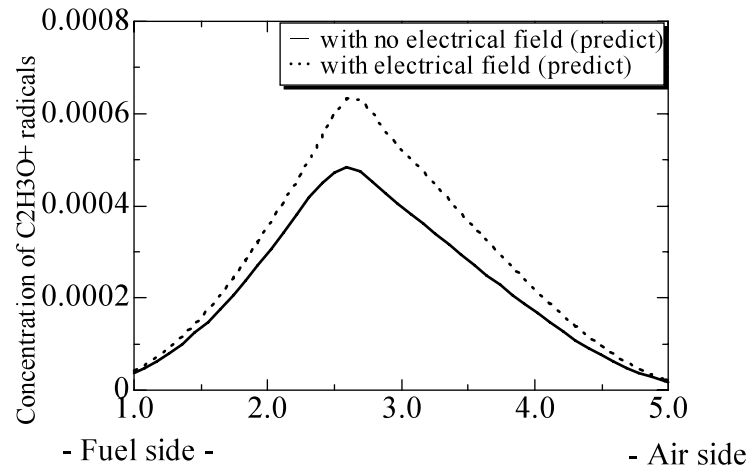

Distance from the burner surface $\mathrm{mm}$

第 10 図計算結果 $\left(\mathrm{C}_{2} \mathrm{H}_{3} \mathrm{O}^{+}\right.$分布 $)$

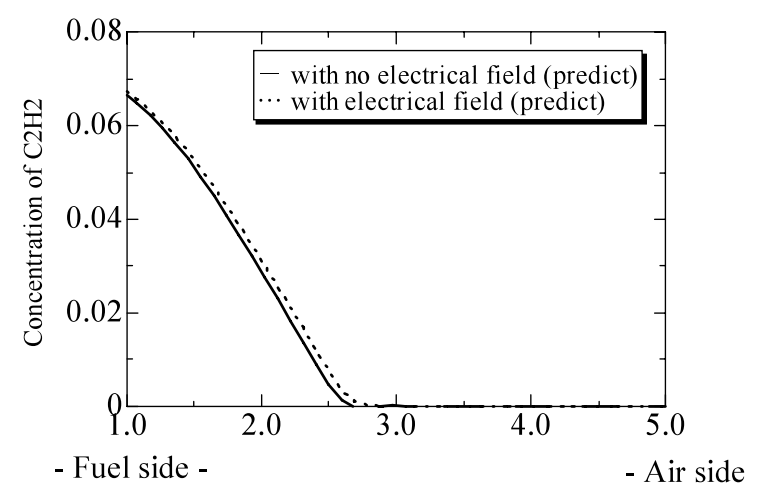

Distance from the burner surface $\mathrm{mm}$

第 11 図計算結果 $\left(\mathrm{C}_{2} \mathrm{H}_{2}\right.$ 分布 $)$

ンの生成を示す第 1 表の (4)，(8)，(9) 式の反応が促進され たことによると考えられる．また，(4) 式の反応物であり， かつ (8) 式の反応物の $\mathrm{C}_{3} \mathrm{H}_{3}^{+}$イオンを (7) 式において生成 するために使われる $\mathrm{C}_{2} \mathrm{H}_{2}$ の濃度分布は第 11 図に示す通 りイオン風により空気側に移動している .これより火炎帯 に近づき活発に反応したことで $\mathrm{C}_{2} \mathrm{H}_{3} \mathrm{O}^{+}$イオンの生成量 が増えたという機構が考えられる.また質量分率のピーク 值を示す半径方向位置は印加後わずかに空気側に移動して いる.これはクーロンカによりイオン自体か陽極から陰極 に向かって移動していることを示している.第 12 図に火 炎帯近傍における半径方向速度分布を示す．電界を印加す ると, 火炎温度が最も高い $r=2.7 \mathrm{~mm}$ 付近において印加 前よりも速度か増大することが示されている.この結果は， 電界の印加がイオン風を誘起し，弚れにより空気側（負極 側) への流速を増大させていることを示しているものと考 えられる。

\section{4. 結論}

本研究では, 電界中における対向流拡散火炎の挙動をイ オン風の影響という観点から調へたた . 兴のため多孔質円筒 バーナーを用いて形成された火炎を対象とした実験および 二次元円筒座標を利用した数值計算が行われた . 兴の結果， 得られた結論は以下の通りである .

1 . 直流 $200[\mathrm{~V}]$ の電界を印加することにより火炎帯か陽 極側から陰極側へと移動することか観察された . また , 温度

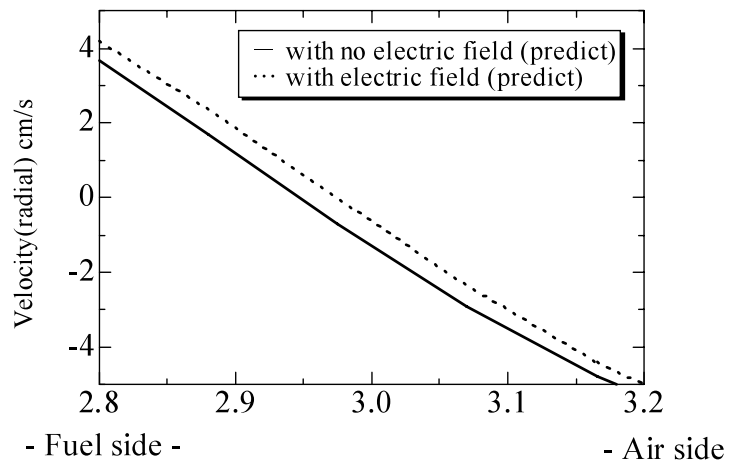

Distance from the burner surface $\mathrm{mm}$

第12 図計算結果 (半径方向速度分布)

分布および $\mathrm{OH}$ 濃度分布も同樣に移動することがわかった .

2 . 数値計算から, 電界印加により火炎帯か陰極側入移

動することが認められた．電界印加による温度分布および $\mathrm{OH}$ 濃度分布の移動が良く再現されていることがわかった . また半径方向速度は陰極側入向かって $1 \mathrm{~cm} / \mathrm{s}$ 程度増大す ることが示された .

3 . 詳細な陽イオン分布および半径方向速度分布から，イ オン風による火炎挙動の変化を説明することができた .

\section{参 考 文 献}

1) Fox, J. S. and Mirchandani, I.: Influence of Electric Fields on Burning Velocity, Combust. Flame, 22 (1974), pp. 267-268.

2) Jaggers, H. and Engel, A.: The Effect of Electric Fields on the Burning Velocity of Various Flames, Combust. Flame, 16 (1971), pp. 275-285.

3) Bowser, R. S. and Weinberg, F. J.: The Effect of Direct Electric Fields on Normal Burning Velocity, Combust. Flame, 18 (1972), pp. 296-300.

4) Jones, F. L., Becker, P. M. and Heinsohn, R. J.: A Mathematical Model of the Opposed-Jet Diffusion Flame: Effect of an Electric Field on Concentration and Temperature Profiles, Combust. Flame, 19 (1972), pp. 351-362.

5) $\mathrm{Hu}$, J., Rivin, B. and Sher, E.: The Effect of an Electric Field on the Shape of Co-Flowing and Candle-Type Methane-Air Flames, Exp. Thermal Fluid Sci., 21 (2000), pp. 123-133.

6) Tsuji, H. and Yamaoka, I.: The Counterflow Diffusion Flame in the Forward Stagnation, Eleventh Symposium (International) on Combustion, 1967, pp. 979-984.

7) Xie, L., Kishi, T. and Kono, M.: Investigation on the Effect of Electric Fields on Soot Formation and Flame Structure of Diffusion Flames, Twenty Fourth Symposium (International) on Combustion, 1992, pp. 1059-1066.

8) Eckbreth, A. C.: Laser Diagnostics for Combustion Temperature and Species, Abacus Press, Tunbridge Wells, 1987, pp. 301-361.

9) James, L. and Felix, J. W.: Electrical Aspects of Combustion, Clarendon Press, Oxford, 1969, pp. 315-340.

10) Heinsohn, R. J., Thillard, S. V. and Becker, P. M.: Temperature Profiles of an Opposed-Jet Diffusion Flame Subjected to an Electric Field, Combust. Flame, 13 (1969), pp. 442-445.

11) Smith, G. P., Golden, D. M., Frenklach, M., Moriarty, N. W., Eiteneer, B., Goldenberg, M., Bowman, C. T., Hanson, R. K., Song, S., Gardiner, W. C., Lissianski, V. and Qin, Z.: GRI-Mech 3.0 Web site, http://www.me.berkeley. edu/gri_mech/, 1999.

12) Pedersen, T. and Brown, R. C.: Simulation of Electric Field Effects in Premixed Methane Flames, Combust. Flame, 94 (1993), pp. 433-448. 